\title{
Analysis of Leptin Gene Polymorphism in Assam Hill Goat and their Association with Growth
}

\author{
R. G. Sarmah ${ }^{1^{*}}$, S. Laskar ${ }^{2}$, N. Nahardeka ${ }^{3}$, P. Borah ${ }^{2}$ and B. Das ${ }^{2}$ \\ ${ }^{1}$ Department of Animal Biotechnology, College of Veterinary Science, \\ Khanapara, Assam, India \\ ${ }^{2}$ College of Veterinary Science, Khanapara, Assam, India \\ ${ }^{3}$ ICAR-AICRP on Goat Improvement, Assam, India \\ *Corresponding author
}

Keywords

Assam hill goat,

Leptin gene,

Polymorphism, PCR-RFLP

Article Info

Accepted:

08 June 2020

Available Online:

10 July 2020
A B S T R A C T

Leptin gene could be considered as a hotspot gene and its role in meat and milk production makes it a candidate for the search of molecular markers related to meat production as well as meat quality in goats. The present investigation was carried out to study the occurrence of polymorphism in Leptin $(L E P)$ gene in Assam Hill Goat and to associate the polymorphic gene, if any, with body weights of the goats at 0 day, 3, 6, 9 and 12 months of age. A total of 256 blood samples were collected from male goats maintained at different field units and at the Goat Research Station, Assam Agricultural University, Burnihat under the "ICAR-All India Coordinated Research Project on Goat Improvement". PCR-RFLP was analysed with $C V i Q$ I restriction enzyme with restriction site as $\mathrm{G}^{\wedge} \mathrm{TAC}$. Multiple alignment of the sequences of the representative amplicons revealed no nucleotide mutation at the restriction site. All the 256 samples produced two fragments of $124 \mathrm{bp}$ and $400 \mathrm{bp}$ in 12\% Polyacrylamide Gel Electrophoresis (PAGE) revealing monomorphic banding patterns. As no polymorphism could be established, further study on the association of polymorphic genotypes with the body weights at different ages could not be carried out.

\section{Introduction}

Goat substantially contributes to the rural economy. It plays an important role in providing livelihood to the poor sections of the society. India possesses the second largest goat population in the world with 135.17 million goats $(26.40 \%$ of the country's total livestock) which is $15.68 \%$ of total goat population in the world (Basic Animal Husbandry and Fisheries Statistics, 2014). Eastern and North-Eastern part of India is rich in breeds of goat like Assam Hill goat, SumiNe, Ganjam, Black Bengal etc which are known to be of good quality meat type. Almost the entire population of Northeastern region of India is non-vegetarian and chevon is the meat of choice having no religious 
taboo. Being a high-quality protein source, it is the choicest meat in the domestic market. Further, the meat does not have any social taboo and is accepted by all sections of people. It contains low cholesterol and high level of iron and potassium as compared to other types of meat (Correa, 2011) Moreover, it is leaner than other red meats and the fat has desirable fatty acids (Kumar, 2007).

The goat population of Assam is 6.169 million, contributing $4.56 \%$ of total goat population of India (Basic Animal Husbandry and Fisheries Statistics, 2014). The Assam Hill goat is a newly registered breed distributed throughout the state of Assam possessing high quality meat and good adaptability characteristics to local high humid agro-climatic condition. The reproductive traits of the goat breed include prolific nature of kidding, early sexual maturity and early kidding age.

However, the Assam Hill goat is smaller in size with lower birth weight, weaning weight and matured body weight as compared to other breeds of goat found in India. Even though having good quality genetic resources may be, this is the reason behind the wide gap between the demand and the supply of meat in Assam. This gap could be bridged by enhancing the goat productivity by improving the growth performance as well as reproductive efficiency of the Assam Hill Goat.

Molecular genetics has played a key role in discovering individual genes or candidate genes with substantial effects on the traits of economic importance. A total of 271 candidate genes have been detected in goats (Supakorn, 2009). Leptin gene is one of the potential genes that are involved in the metabolism and growth of animals. The gene is mapped on chromosome 3 and consists of three exons which are separated by two introns. The three exons of the leptin gene cover approximately $15 \mathrm{~Kb}$ of genomic DNA. The entire coding region is contained in exons $2 \& 3$ which are separated by a $2 \mathrm{~Kb}$ intron (Agarwal et al., 2009). The possible effects of LEP on growth traits of goat kids are unknown and little research has been conducted involving LEP in goats. The objective of the present study was to determine polymorphism of LEP gene in Assam Hill goats of Assam, India and to associate the polymorphic gene, if any with the body weights at 0 day and 3, 6, 9 and 12 months of age.

\section{Materials and Methods}

\section{Location}

Data pertaining to a total of 256 male goats were utilized in the present study. The goats were reared by the registered farmers of different field units as well as head quarter located at Goat Research Station, Assam Agricultural University under the ICAR sponsored project, "ICAR- AICRP on Goat Improvement". The average temperature of the area ranged from 14.7 to $32.3^{\circ} \mathrm{C}$ and the relative humidity ranged between 51.2 and $93.7 \%$. During the study period, the average annual rainfall was recorded to be 2818.0 millimetres. The location of the study lies between $90.48^{\circ}$ and $92.22^{0}$ (East) longitude and $20.09^{\circ}$ and $26.95^{\circ}$ (North) latitude.

\section{Blood collection and DNA extraction}

From the jugular vein of the goats under study, a volume of five $\mathrm{ml}$ of blood was collected aseptically in a vacutainer tube containing $2.7 \%$ EDTA as an anticoagulant. The samples were brought from the field units to the laboratory in double walled ice-boxes containing ice packs and stored at $-20^{\circ} \mathrm{C}$ until the genomic DNA was extracted. 
Genomic DNA was isolated from the whole blood collected $(5 \mathrm{ml})$ by following standard protocol of Sambrook and Russell, 2001 with slight modification. The purity of genomic DNA was assessed by Nanodrop Spectrophotometer (Picodrop, Model: Picopet 01) and Optical Density (OD) values were measured at 260 and $280 \mathrm{~nm}$ which indicated the amount of DNA and the amount of protein in the given sample respectively.

The concentration of genomic DNA was estimated spectrophotometrically by taking OD value at $260 \mathrm{~nm}$. Horizontal submarine agarose gel electrophoresis was performed to check the quality of the isolated genomic DNA samples and was examined under gel documentation system (Gel Doc XR+, BioRad). The quality of DNA was checked on $1.5 \%$ agarose gels stained with ethidium bromide.

\section{Amplification of $G H$ Gene by PCR}

The sequences of the forward and reverse primers for the amplification of the $L E P$ gene in the present study were:

Forward:

5' - TGTGATGGACTCTTTGGATG -3' (Designed, $\mathrm{T}_{\mathrm{m}}$ Values: $52.2{ }^{\circ} \mathrm{C}$ )

Reverse :

5'- CCTCCTCCTTTGTTCTACTG -3' (Designed $\mathrm{T}_{\mathrm{m}}$ Values: $52.1^{\circ} \mathrm{C}$ )

PCR was performed in a $25 \mu \mathrm{l}$ reaction mixture containing $10.5 \mu \mathrm{l}$ NFW; $0.5 \mu \mathrm{l}$ Primer F; $0.5 \mu \mathrm{l}$ Primer R; $12.5 \mu 1$ master mix and $1 \mu \mathrm{l}$ of genomic DNA template. Thermal cycling conditions of PCR are given in Table 1. The PCR products, thus obtained were separated and confirmed by horizontal submarine agarose gel electrophoresis $(1.5 \%)$ using 100 bp DNA ladder 1X TAE buffer (80 $\mathrm{V}$ for 70 minutes). (Fig.1)

\section{Restriction fragment length polymorphism (RFLP) analysis}

The polymorphism was performed by Polymerase Chain Reaction-Restriction Fragment Length Polymorphism (PCRRFLP). Reaction mixer for RFLP of the gene under study was prepared with $0.4 \mu \mathrm{l}$ of restriction endonuclease, $C V i Q \mathrm{I}, 2.0 \mu \mathrm{l}$ of buffer, $8.0 \mu \mathrm{l}$ of PCR product and $9.6 \mu \mathrm{l}$ of NFW amounting a total volume of $20 \mu \mathrm{l}$ and then subjected to digestion at $25^{\circ} \mathrm{C}$ for 120 min. The digested PCR-RFLP product was subjected to $12 \%$ Polymerase Agarose Gel Electrophoresis (PAGE) carried out at $100 \mathrm{~V}$ for 2 hours, followed by staining with $0.5 \mu 1$ of ethidium bromide. The digested fragments were visualized and documented using UV light and Gel Documentation System (Gel Doc XR+, Bio-Rad) and were analyzed by comparing with 50 bp DNA ladder. (Fig. 2)

\section{Sequence analysis}

The PCR products were sent for sequencing to first base DNA sequencing division, Malaysia, which were sequenced by automated DNa sequencer following Sanger's dideoxy chain termination method (Sanger et al., 1977). The sequences were analyzed by using Clustal $\mathrm{W}$ method of DNASTAR Software (Lasergene, USA) to generate sequence alignment reports and residue substitution.

\section{Results and Discussion}

Amplification of LEP gene with the designed primers resulted in generation of $524 \mathrm{bp}$ DNA fragment (Fig 1) which is consistent with the expected size as estimated from their gene sequence information. In order to determine the polymorphism, if any in amplified fragment of the gene under study, a restriction enzyme $C V i Q \mathrm{I}$ having recognition site as $\mathrm{G}^{\wedge} \mathrm{TAC}$ was used to digest the $524 \mathrm{bp}$ 
fragment. The RFLP analysis of all the samples revealed single type of banding pattern yielding two fragments, each of 124 bp and $400 \mathrm{bp}$ (Fig. 2). Multiple alignment of the sequences of the representative amplicons revealed no nucleotide mutation at the restriction site. The monomorphic banding patterns of the digested product revealed that all the animals under study possessed similar genotype. Though the objective of the present study was to determine polymorphism of $L E P$ gene in Assam Hill goats and to associate the polymorphic gene, if any with the body weights at 0 day and 3, 6, 9 and 12 months of age, the association study could not be carried out due to the presence of similar genotype. Leptin gene polymorphism has not been thoroughly studied in Indian goat breeds and research findings relevant to the present study are scanty and so this result is a good authentication for it. Limited number of samples screened might be the factor for absence of any polymorphism in the fragment of the gene evaluated. Further, presence of only a single genotype in the fragment of $L E P$ gene under study may be an indication that the genotype present might be the favourable genotype without any mutation.

However, Maitra et al., (2014) conducted a study for preliminary identification and characterisation of leptin gene polymorphism in Indian goats and discovered seven novel SNPs. Wang et al., (2015) detected six novel SNPs in 411 individuals from five Chinese goat breeds using DNA sequencing. Jonasa et al., (2016) revealed three SNPs in LEP gene, one in exon 2 and two in exon 3.

The present study showed monomorphic banding patterns in all the studied samples of Assam Hill goat with respect to CViQI restriction site of $L E P$ gene which indicated that all the animal possessed similar genotype.

Table.1 Thermal cycling conditions of PCR

\begin{tabular}{|c|c|c|c|c|c|}
\hline Gene & $\begin{array}{c}\text { Initial } \\
\text { denaturation }\end{array}$ & Denaturation & Annealing & Extension & $\begin{array}{c}\text { Final } \\
\text { extension }\end{array}$ \\
\hline$L E P$ & $\begin{array}{c}94{ }^{\circ} \mathrm{C} \text { for } 4 \\
\text { minutes }\end{array}$ & $\begin{array}{c}94{ }^{\circ} \mathrm{C} \text { for } 30 \\
\text { seconds }\end{array}$ & $\begin{array}{c}49{ }^{\circ} \mathrm{C} \text { for } 30 \\
\text { seconds }\end{array}$ & $\begin{array}{c}72{ }^{\circ} \mathrm{C} \text { for } 45 \\
\text { seconds }\end{array}$ & $\begin{array}{c}72{ }^{\circ} \mathrm{C} \text { for } 5 \\
\text { minutes }\end{array}$ \\
\hline & & 35 cycles & & & \\
\hline
\end{tabular}

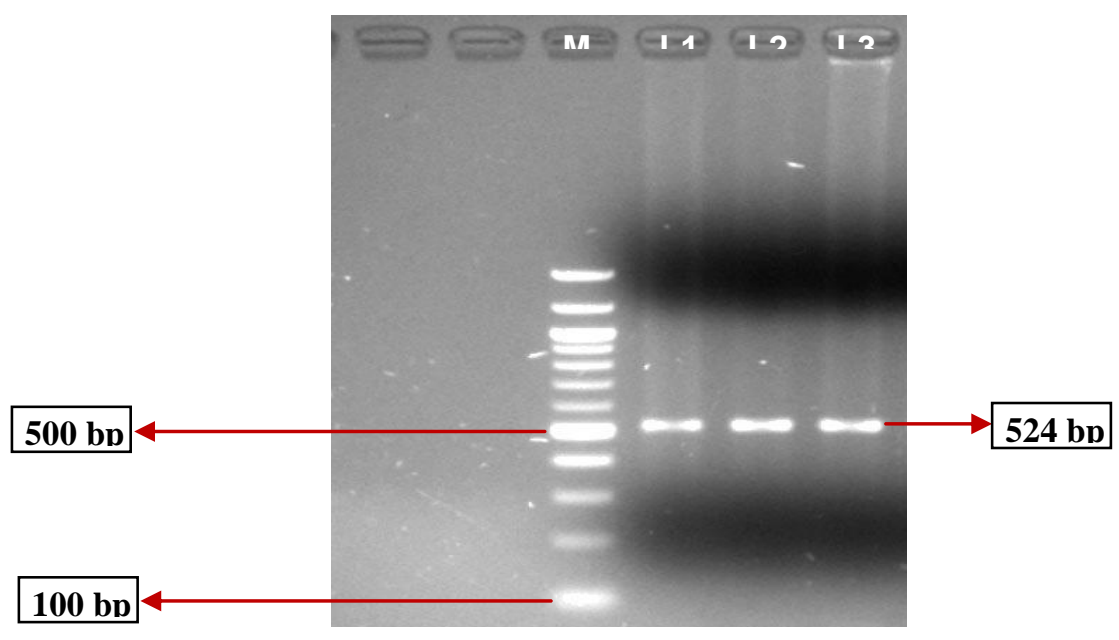

Fig.1 Amplified product of lep gene

L1 to L3 = Amplified LEP gene; M=100 BP Ladder 


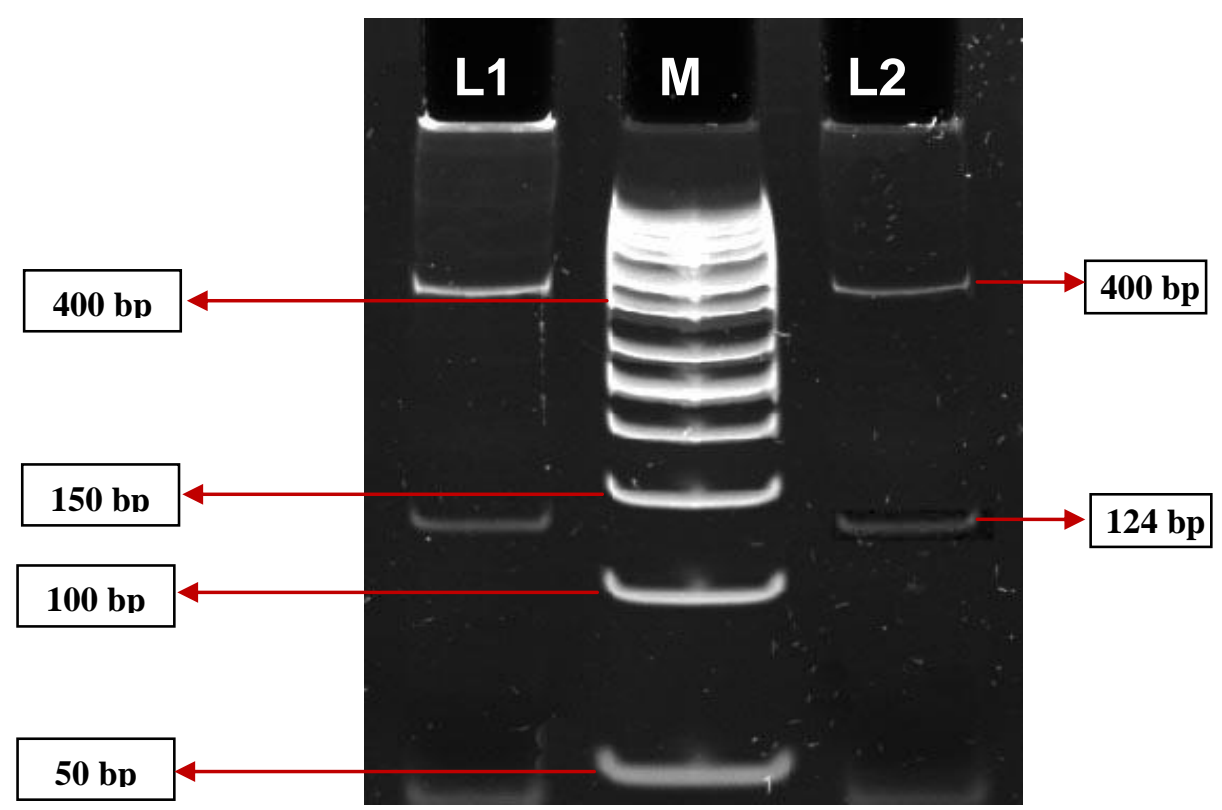

Fig.2 PCR-RFLP of LEP gene (12\% page)

L1 and L2= AA Genotype; $\mathrm{M}=50$ bp ladder

This result prevented further study on association of polymorphic genes with the body weight at different ages. However, considering the economic importance of the meat quality trait to the livestock industry, further research on substantially large number of goats, on fragments other than the one under study and with the use of same fragments but another set of restriction enzymes may be carried out to find polymorphism as well as to establish association between polymorphism, if any, with body weights at different ages.

\section{Acknowledgement}

Authors acknowledge the facility provided by the ICAR for the project "AICRP on goat Improvement" for carrying out the research work.

\section{References}

Agarwal, R., Rout, P.K. and Singh, S. K. (2009). Leptin: A biomolecule for enhancing livestock productivity. Indian
J. Biotech., 8: 169-176.

Basic Animal Husbandry and Fisheries Statistics (2014). Department of Animal Husbandry, Dairying and Fisheries, Ministry of Agriculture, Govt. of India.

Correa, J.E. (2011). Nutritive value of goat meat. Alabama Cooperative Extension System. 1-4.

Jonasa, E., Martin, G.B., Celi d, P., Li, L., Soattina, M., Thomsona, P.C. and Raadsma, H.W. (2016). Association of polymorphisms in leptin and leptin receptor genes with circulating leptin concentrations, production and efficiency traits in sheep. Small Rumin. Res., 136: 78-86.

Kumar, S. (2007). Commercial goat farming in India: an emerging agri-business opportunity. Agric Econ, 20:503-520

Maitra, A., Sharma, R., Pandey, A.K., Singh, L.V., Mandakmale, S.D. and Mishra, B.P. (2014). Preliminary identification and characterisation of leptin gene polymorphism in Indian goats. J. Appl. Anim. Res., 42(1): 118-122.

Sambrook, J. and Russell, D.W. (2001). 
Molecular Cloning: A laboratory manual, $3^{\text {rd }}$ Edn., Cold Spring Harbor laboratory Press, New York.

Sanger, F., Nicklen, S. and Coulson, A.D.(1977). DNA sequencing with chain terminating inhabitor. Proceedings of National Academy of Science USA,74: 5436-5467.

Supakorn, C. (2009). The Important
Candidate Genes in Goats. Walailak $J$. Sci. Tech, 6: 17-36.

Wang, C., Zhang, H., Niu, L., Guo, J., Jia, X., Wang, L., Zhang, L.L.H. and Zhong, T. (2015). The novel SNPs of leptin gene and their associations with growth traits in Chinese Nanjiang Yellow goat. Research paper, 572 (1): 35-41.

\section{How to cite this article:}

Sarmah, R. G., S. Laskar, N. Nahardeka, P. Borah and Das, B. 2020. Analysis of Leptin Gene Polymorphism in Assam Hill Goat and their Association with Growth. Int.J.Curr.Microbiol.App.Sci. 9(07): 639-644. doi: https://doi.org/10.20546/ijcmas.2020.907.073 